Portland State University

PDXScholar

\title{
Written narrative texts of language impaired and normal adolescents
}

\author{
Kevin Jon Penner \\ Portland State University
}

Follow this and additional works at: https://pdxscholar.library.pdx.edu/open_access_etds

Part of the Speech Pathology and Audiology Commons Let us know how access to this document benefits you.

\section{Recommended Citation}

Penner, Kevin Jon, "Written narrative texts of language impaired and normal adolescents" (1991). Dissertations and Theses. Paper 4190.

https://doi.org/10.15760/etd.6073

This Thesis is brought to you for free and open access. It has been accepted for inclusion in Dissertations and Theses by an authorized administrator of PDXScholar. Please contact us if we can make this document more accessible: pdxscholar@pdx.edu. 
AN ABSTRACT OF THE THESIS OF Kevin Jon Penner for the Master of Science in Speech Communication with an emphasis in Speech-Language Pathology presented on May 29, 1991.

Title: Written Narrative Texts of Language Impaired and Normal Adolescents.

APPROVED BY THE MEMBERS OF THE THESIS COMMITTEE:

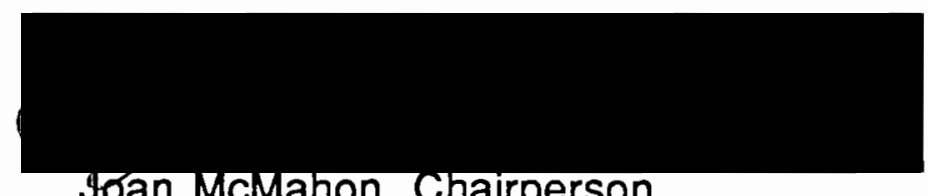

soan McMahon, Chairperson

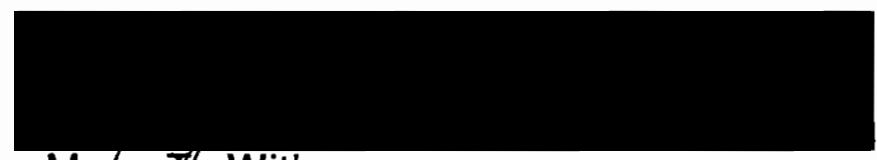

Mafy V. Withers

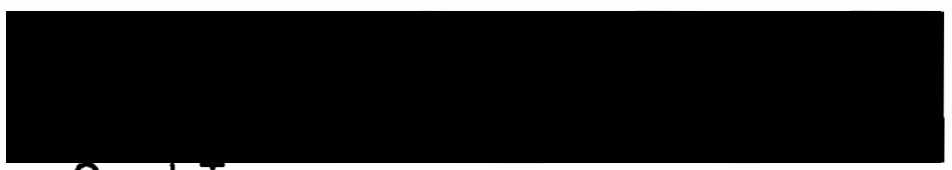

Carol Tama

Classroom teachers frequently refer adolescents to speechlanguage pathologists for language skills evaluations. Many of the traditional evaluation tools of the speech-language pathologist focus on the student's oral language skills. The first indication to the classroom teacher that there may be a language problem, however, is usually from the student's written classwork. Very few written language assessment tools are available which give speech- 
language pathologists information regarding linguistic units which can be viewed as communication acts. This paper focuses on one particular discourse unit - the written narrative. Narratives are a natural form of thought and demonstrate how a person organizes and views the world around them. Narratives can be analyzed from the perspective of their "texts," how the writer links individual sentences together to create a cohesive discourse.

The purpose of this study was to compare the written narratives of language impaired and normal adolescents. Two questions were addressed in this study. First, are there differences in texts between language impaired and normal adolescents? And second, do the written narratives of a personal experience and imaginary event produce different texts in language impaired and normal adolescents?

Forty high school students from the Beaverton School District comprised the two groups of subjects with 20 in each group. The experimental group included students who had been diagnosed as language impaired and who were receiving speech and language services. The control group included students who were normal in language skills, i.e., enrolled in regular classrooms and not on IEPS. The subjects were instructed to write two narratives, one about a personal experience, e.g. how your day usually goes, and the other about an imaginary event, with the starter "One day a plane was flying through the towering mountains." No time limit was set for the completion of the tasks. 
This study used the analysis of cohesion described by Halliday and Hasan (1976) to score the written narratives. Five types of cohesive devices were measured: referents, substitutions, ellipsis, conjunctions, and lexicals. Scores were the total number of each cohesive device used for each written narrative for each subject.

The results of both questions were statistically analyzed through the use of a two-way analysis of variance (ANOVA) for each cohesive device to determine the effects of group (language impaired or normal), task (personal experience or imaginary event), and group/task interaction upon the five dependent variables (referent, substitution, ellipsis, conjunction, and lexical). The results indicated that there was a significant difference $(p \leq .05)$ between the groups on all five cohesive device measures, and a significant difference of task on referent and lexical only. Only one cohesive device, i.e., substitution, showed an interaction effect between task and group. Both groups used more cohesive devices on the imaginary event than the personal experience task.

The significant differences were further analyzed with $5-$ tests to determine if the group effects were different according to task and if the task effects were different according to group. First, the group effects showed a significant difference on all cohesive device measures for the personal experience task, but not significant on any for the imaginary event. Secondly, the task 
effects were significant for the normal and language impaired subjects for the referent device only. In all cases the normal subjects performed better than the language impaired subjects.

The results of the narrative analysis revealed that there is a significant difference between the two groups of subjects, with the normal subjects performing better. Also there was a significant difference between the performance on the two different tasks, with more cohesive devices used on the imaginary event task than the personal experience task. 
WRITTEN NARRATIVE TEXTS OF LANGUAGE IMPAIRED

AND NORMAL ADOLESCENTS

by

KEVIN JON PENNER

A thesis submitted in partial fulfillment of the requirements for the degree of

\author{
MASTER OF SCIENCE \\ in \\ SPEECHCOMMUNICATION \\ with an emphasis in \\ SPEECH-LANGUAGE PATHOLOGY \\ Portland State University \\ 1991
}


TO THE OFFICE OF GRADUATE STUDIES:

The members of the Committee approve the thesis of Kevin Jon Penner presented May 29, 1991.

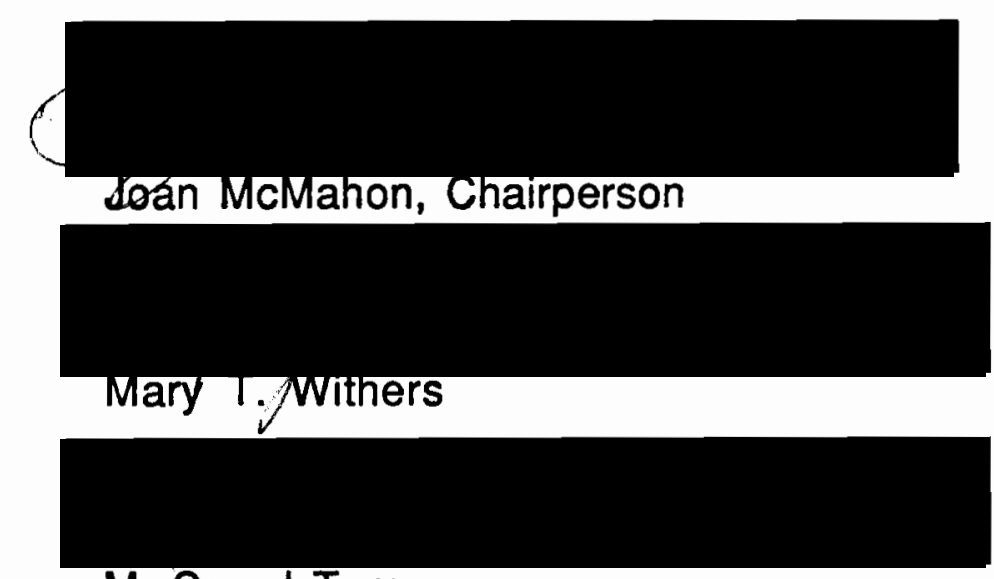

M. Carrol Tama

\section{APPROVED:}

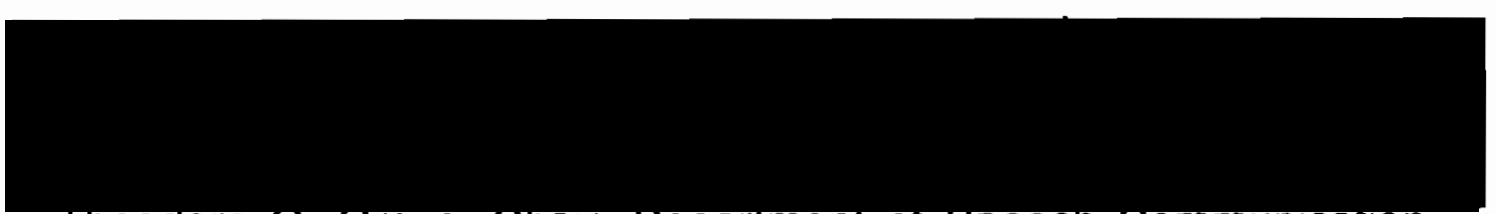

Ineodore G. Grove, Chair, Department of Speech Communication

C. Willam Savery, Interim Vice Proxost for Graduate Studies and Research 


\section{ACKNOWLDGEMENTS}

I want to thank all of my family and friends who have assisted and encouraged me in the completion of this thesis. First of all, I wish to thank Joan McMahon for her advice and support. Her incredible patience and restraint has all but stopped her from "painting my head red" at times. Without her, this thesis would not be in existence.

I also wish to thank Mary T. Withers and Carol Tama who have provided good advice and encouragement to complete this research.

I'd also like to extend thanks to Tig Brown, for her assistance in sharing her data and answering some annoying 'little' questions for me. And to Debbie Sullivan and Barbara Kienow for helping with the inter-rater reliability.

To my parents and in-laws who waited so patiently for me to complete my thesis without a 'nagging' word.

And finally, thanks to my family. Jan, thank you for always being supportive and loving. To Ashlee, Timothy, and Jonathan, thank you for your patience. Now we can go camping and fishing. 


\section{TABLE OF CONTENTS}

PAGE

ACKNOWLEGEMENTS . . . . . . . . . . . . .

LIST OF TABLES . $\quad . \quad$. $\quad . \quad$. $\quad . \quad$. $\quad . \quad$ viii

LIST OF FIGURES . $\quad . \quad$. $\quad . \quad$. $\quad . \quad$. $\quad . \quad$. $\quad$ ix

CHAPTER

I INTRODUCTION AND STATEMENT OF PURPOSE . 1

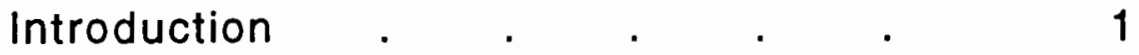

Statement of Purpose . . . . . . . 3

Definition of Terms . $\quad . \quad$. $\quad . \quad 4$

II REVIEW OF THE LITERATURE . $\quad$. $\quad$. $\quad$. 5

Development of Written Language . . . 6

Relationship of the Language Modes . 8

Methods of Assessment $\quad . \quad$. $\quad . \quad 10$

Assessment of Written Language . . . 11

Summary . $\quad . \quad . \quad . \quad . \quad . \quad . \quad 13$ 
CHAPTER

PAGE

III METHODS AND PROCEDURES . . . . . 14

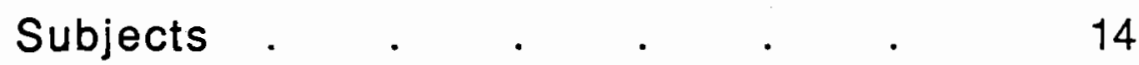

Experimental Subjects $\quad$. $\quad$. 14 Control Subjects . . . . $\quad$. 15

Instrumentation . $\quad . \quad \ldots \quad . \quad . \quad . \quad 16$

Procedures for this Study . . . . . $\quad 16$

Investigator Reliability . . . $\quad 17$

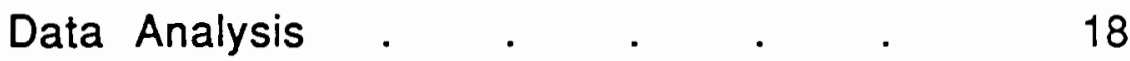

Limitations of this Study . . . . . $\quad 19$

IV RESULTS AND DISCUSSION . . . . . 20

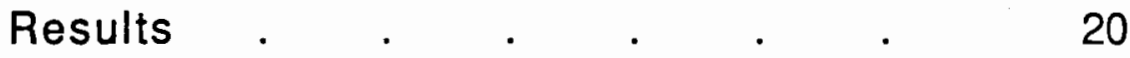

Discussion . $\quad . \quad . \quad . \quad . \quad . \quad 31$

V SUMMARY AND IMPLICATIONS . . . . 33

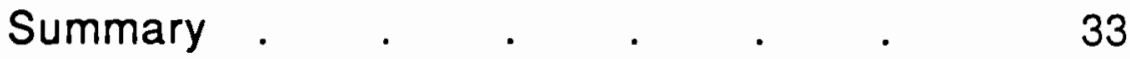

Clinical Implications . . . . . . $\quad 36$

Research Implications . . . . . $\quad 36$ 
PAGE

REFERENCES

APPENDICES
A TYPESOF COHESION $\quad$. . . . . . . . $\quad . \quad 42$
B LETTER TO PARENTS FOR INFORMED CONSENT . 48
C PERSONAL EXPERIENCE FORM-EXAMPLE . . 50
D IMAGINARY EVENT FORM-EXAMPLE . . . . 52
E ANALYSIS OF COHESION SCORING PROCEDURES . 54
F TRAINING MATERIAL FOR INVESTIGATOR RELIABILITY 56
G HUMAN SUBJECTS INITIAL REVIEW . . . . 63
H EXAMPLES OF SCORED NARRATIVES . . . 68 


\section{LIST OF TABLES}

I Two-way Analysis of Variance of Language Impaired and Normal Adolescents' Written Narratives on Task A (Personal Experience) and Task B (Imaginary Event)

II Means and Standard Deviations for Task A (Personal Experience) and Task B (Imaginary Event) Combined for the Language Impaired and Normal Groups

III Means and Standard Deviations Combined for the Language Impaired and Normal Groups for Task A (Personal Experience) and Task B (Imaginary Event)

IV t-test Results on Cohesive Devices Found To $\mathrm{Be}$ Significant by the Two-way ANOVA for the Language Impaired and Normal Adolescent Groups for Task A (Personal Experience).

V t-test Results on Cohesive Devices Found To Be Significant by the Two-way ANOVA for the Language Imapired and Normal Adolescent Groups for Task B (Imaginary Event) .

VI t-test Results on Cohesive Devices Found To Be Significant by the Two-way ANOVA Between Task $A$ and Task $B$ for the Language Impaired Group 
VII t-test Results on Cohesive Devices Found To Be Significant by the Two-way ANOVA Between Task A and Task B for the Normal Adolescent Group 


\section{LIST OF FIGURES}

FIGURE

PAGE

1. The Developmental Progression of Language .

2. Means ( $x$ ) and Standard Deviations (SD) of

Language Impaired and Normal Adolescents

Use of Cohesive Devices In Written

Narratives for Personal Experiences

(Task A) and Imaginary Events (Task B).

3. Comparison by Group-Task A (PE) . . . . 26

4. Comparison by Group-Task B (IE) . . . . 26

5. Comparison of Tasks for Language Im . . 27

6. Comparison of Tasks for Normals . . . $\quad 27$ 


\section{CHAPTER I}

\section{INTRODUCTION AND STATEMENT OF PURPOSE}

\section{INTRODUCTION}

The average adolescent incorporates the use of four modes of communication (listening, speaking, reading, and writing) each school day in the academic setting. According to Werner (Gajewski and Mayo, 1989), listening is the primary mode utilized, followed in rank order by speaking, reading, and writing. Adolescent students are most often evaluated, however, on their level of knowledge through the written language mode including essays, classroom assignments, quizzes, and tests (U.S. Department of Education, 1986). Therefore, a language problem should become more apparent to the teacher from the student's written language than their spoken language. According to Isaacson (1985), a student's written language is often the first indication to the classroom teacher that there might be a serious learning problem. When a classroom teacher refers a student for a language evaluation, a sample of the student's written language is useful for the speech-language pathologist to better understand the teacher's concerns (Peterson and Marquardt, 1981), determine approximately where the student is functioning, what differences exist, and where to begin intervention 
by comparing the collective information with norms (Weiss and Lillywhite, 1981).

Many diagnostic language evaluations administered to adolescents include formal standardized tests and informal oral language samples. Written language samples, however, are often overlooked due to time constraints, lack of knowledge and experience in analysis, or the inability to design an intervention program to utilize its information. As a result of these factors, the field of Speech-Language Pathology has focused primarily on adolescents' conversational skills, essentially neglecting their writing skills (Phelps-Gunn and Phelps-Teraski, 1982).

Currently there is no test available to the speech-language pathologist that evaluates a student's writing process, from brainstorming the topic to the final edited form. Rather, most written language tests are designed to look at a specific area of a student's writing skills (e.g., morphology or syntax). While these tests give an evaluator valuable information about specific rules of sentence-discourse units, they do not provide information regarding linguistic units that are larger and can be viewed as communication acts. This paper focuses on one particular discourse unit - the written narrative. Narratives are a natural form of thought and a primary act of the mind (Westby, Van Dongen, and Maggart, 1989), demonstrating how a person organizes and makes sense of the world around them. Narratives can be a real or imaginary report of what happened (Lahey, 1988). They can be analyzed from the perspective of their "texts," the linguistic devices which the writer uses to link 
individual sentences together to create a cohesive discourse (Johnston, 1982).

In order to provide a data base to assist a speech-language pathologist in the identification of language impaired adolescents and the development of an intervention program, the written narrative texts of language impaired adolescents should be compared to those of normal adolescents.

\section{STATEMENT OF PURPOSE}

The purpose of this study was to compare the written narrative texts of language impaired and normal adolescents. This study also compared the written narrative texts of a personal experience and an imaginary event (nonfamiliar experience). The following questions were addressed:

1) Are there differences in texts between language impaired and normal adolescents?

2) Do the written narratives of a personal experience and an imaginary event produce different texts in language impaired and normal adolescents? 


\section{DEFINITION OF TERMS}

Cohesive devices: the linguistic tools used to tie individual sentences together, creating a text. These tools are: reference, substitution, ellipsis, conjunctions and lexical.

Language Impaired: a student whose language behaviors are different from those expected, considering their chronological age, which interfere with academic success, and have been identified by their school district as such.

Narrative: an account of a personal experience or an imaginary event.

Text: "any passage, spoken or written, of whatever length, that does form a meaningful whole" (Halliday and Hasan, 1976).

Written Language: a specific function of language expression in the visual form of words and sentences. 


\section{CHAPTER II}

\section{REVIEW OF THE LITERATURE}

Currently, the written language skills of adolescent students have become a topic for concern, because of the decline of their language-verbal scores since the mid-1960s. There is a movement to re-emphasize writing skills in the schools (Phelps-Gunn and Phelps-Teraski, 1982).

The classroom teacher relies heavily on written assignments and tests to determine student's grades, both of which are dependent on writing skills. Written language is often the first indicator a classroom teacher has that a student has language-learning problems. To be of assistance to the teacher and to accurately describe the student's language level, a speech-language pathologist needs to determine the student's strengths and weaknesses and analyze their language skills based on a variety of language factors; one of which is their writing skill.

This chapter discusses the development of written language, the relationship of the language modes, and the methods of assessing written language. 


\section{DEVELOPMENT OF WRITTEN LANGUAGE}

By understanding the developmental stages of written language speech-language pathologists can make sure their assessment tools are sensitive to the developmental sequence so that writing skills may be measured in the proper context.

There are two major contrasting theories for the development of writing skills in relationship to language development. The traditional theory, proposed by Myklebust (Phelps-Gunn \& PhelpsTeraski, 1982) indicates that writing develops after other communication modes because of its many complex prerequisites. He developed a hierarchy demonstrating the relationship of each of the four language modes to its stage in the developmental process, as shown in Figure 1.

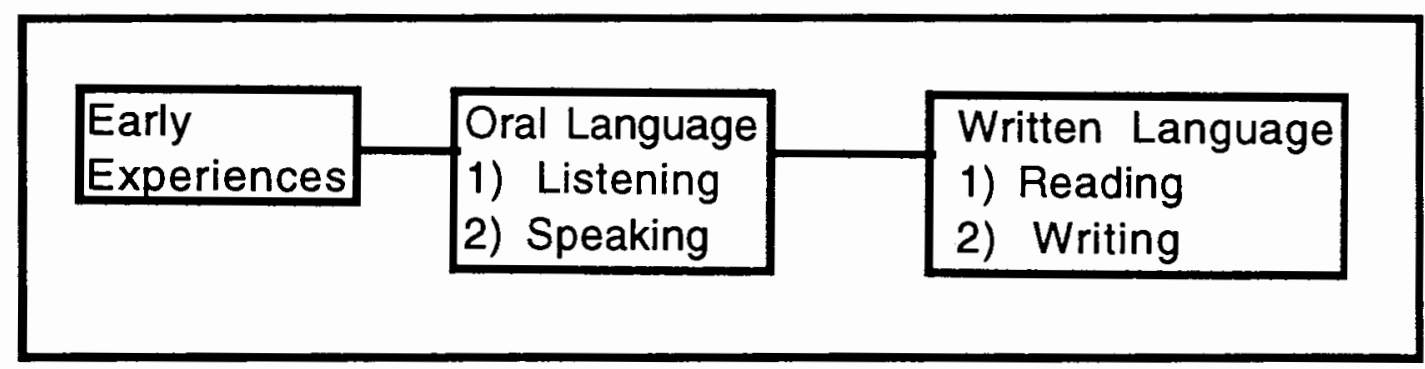

Figure 1. The developmental progression of language.

This diagram is often referred to as the framework for designing language analysis and intervention tools. Language development originates with the early experiences of infancy. The 
oral mode precedes the written and the receptive precedes the expressive. In this theory written language is the final language mode to develop, because of its use of abstract and symbolic skill (Phelps-Gunn \& Phelps-Teraski, 1982). The contrasting theory of development claims that oral and written language systems overlap in their development and are not restricted to oral skills being developed prior to written skills (Poplin, 1983; Moran, 1987). Poplin proposed that written language is an example of form following function. She suggested that a child's scribbling as early as eighteen months is an example of a child communicating a message to their parent even though it was illegible. Other examples cited include, "scribble writing" of "I love you" notes to parents and the imitation of a simple letter format (Heath, 1983; Poplin, 1983). Poplin (1983) also suggested that children attach meaning to their writing before they are able to write words or sentences. Thus, the written form follows function in its development.

Regardless of theory of origin, written language skills continue to develop through the adolescent years. The average adolescent demonstrates the ability to write comparisons, explanations, critiques, hypothetical proposals and abstract selfexpressions (Alley \& Deschler, 1979; Schumaker \& Deschler, 1984). By the time a student reaches junior high it is expected he will have the ability to write at a complex and fairly sophisticated level, with less teacher involvement (Dagenais \& Beadle, 1984). A study by Freedman and Pringle in 1981, concluded that 12-13 year old 
students were able to understand how to develop a written narrative (Brossell, 1986). Loban (1976) reported that high school students tend to elaborate on a topic more while writing than orally.

With this information regarding the normal development of writing, a speech-language pathologist can evaluate more thoughtfully the written language assessment of adolescent students.

\section{RELATIONSHIP OF THE LANGUAGE MODES}

When speech-language pathologists are assessing or intervening on behalf of written language it is also important that they understand that the four modes of language are inter-related. Speech cannot be assessed without also acquiring information in regard to a student's ability to listen. Furthermore, when working on writing with a student, the reading mode is also involved.

Several recent articles have cited the relationship of the four modes of language, their similarities and differences. Horowitz and Samuels (1987) stated that writing, reading, listening, and speaking are all social-interactive in nature. Hoskins (1990) noted that reading could be viewed as listening or interacting with the author, while writing could be viewed as an interaction with a "nonpresent audience." According to Cambourne (1988), reading, writing, speaking, and listening are parallel manifestations of the same function, the mind's desire to create meaning. Similar to reading, writing involves the construction and comprehension of a text. 
Language modes relate in their use (i.e., writing involves reading, speaking involves listening); however, they also involve different skill levels. Chafe (1985) noted that written language is free from time constraints. More time is allowed while writing to organize and reorganize one's thoughts. It can also be more deliberate in its linguistic organization. Writing normally incorporates more intricate syntax and a larger variety of vocabulary (Chafe \& Danielewicz, 1987). According to Chafe (1982), the degree of syntactic integration is greater with written language than spoken language. A student learning to read and spell must develop an awareness of phonology related to print that is different than speech (Hoskins, 1990). The differences in spoken and written language are their linguistic features (Rubin, 1987). One of the many different linguistic features identified by Rubin (1987) was the target audiences. For spoken language the target audience is the listener and for written language the audience is the reader. The audience decodes the message using different skills, one visually (reader) and the other auditorily (listener).

Understanding the development of written language and its relationship to other language modes aids the speech-language pathologist in analyzing, identifying, and remediating written language disorders. The research indicates that there are contrasting views as to the development of written language and its relationships. This would lead to the conclusion that there are different procedures for assessment and interpretation of test results in the area of written language. 


\section{METHODS OF ASSESSMENT}

There are primarily two methods for assessing language skills. The first, atomistic evaluation, establishes a numerical count of distinct features of a written product (e.g., letters per word or words per sentence) in a clinically-structured manner (Lloyd-Jones, 1977). These tests are quick to administer and score. They compare a student's current level of function with others at the same age and cultural group (Bloom \& Lahey, 1978). This type of evaluation, however, is limited to the word or sentence level. Atomistic evaluations fail to provide information regarding a student's ability to compose a unified, organized, coherent, logical, and supported written product (Phelps-Gunn \& Phelps-Teraski, 1982).

The second method of assessment, known as a holistic evaluation, analyzes a variety of language factors to determine an overall skill level. An example of a holistic evaluation procedure would be informal language samples, either oral or written. Samples are less structured and more open-ended than atomistic evaluation tools. Conlan (1986) suggested the most accurate assessment procedure for writing skills would incorporate the advantages of an atomistic testing procedure with the advantages of a holistic procedure by including both methods when assessing writing. 


\section{ASSESSMENT OF WRITTEN LANGUAGE}

Before speech-language pathologists can prescribe the appropriate intervention program to increase a student's writing skills, they need to determine the student's strengths and weaknesses. There is no current assessment procedure which evaluates a student's writing process. Generally, the available assessment tools only evaluate specific skills.

Since most writing is produced in paragraph or essay form, a holistic evaluation would provide the evaluator with the most useful information regarding a student's overall skill level. Writing samples provide valuable examples of a student's written language behaviors and their process for organizing language. Phelps-Gunn \& Phelps-Teraski (1982) state that "actual writing samples are essential and necessary to diagnosing individuals' areas of ability and disability." The use of writing samples provide important information about a student's linguistic system to aid in creating effective intervention strategies (Leonard, Prutting, Perozzi, \& Berkley, 1978).

Westby, Van Dongen \& Maggart (1989) suggest that narratives may help speech-language pathologists to understand some aspects of a student's cognitive and language development that are necessary to communicative competence and being successful in school. Narratives are a natural way of thinking and assist in organizing the world and make some sense out of it. 
Narratives can be either an account of a real or imaginary experience (Lahey, 1988). According to Westby et al. (1989), different narrative functions place different demands on the person relating the experience and the listener or reader. A skill in one type of narrative function does not necessarily assure skill in other types of narrative functions. Britton (1978) confirmed this point, indicating that writers produce wide variations in product measures in relation to the function of the written work. The topic of the narrative might also affect how abstract the account (Vallecorsa and Garriss, 1990). They suggested learning disabled students might overlook feelings and thoughts of characters, rather labeling actions and objects in the account.

Johnston (1982) noted that a narrative can be analyzed as story grammars, scripts, communication events, as well as texts . The term text is used to describe a group of sentences that create a unified whole. It may be spoken or written, of any length. Halliday and Hasan (1976) describe a text as a unit of language in use. It is not defined by its size, like a grammatical unit. Rather, it is best defined by its meaning in context. It is a semantic unit which ties a sentence to the one preceding it, creating a cohesive discourse.

Very little is known about how a child develops these cohesive tools. Research provides us with several studies of the acquisition of demonstrative adjectives and pronouns, anaphoric pronouns, comparative adjectives, determiners, and conjunctions. These investigations, however, were limited to the lexical meanings 
rather than their functions in relation to a text. With the lack of developmental research available on cohesive texts we are limited to the use of the linguistic descriptions of adult usage provided by Halliday and Hasan (1976)(Appendix A).

\section{SUMMARY}

Current literature indicates the need to re-emphasize the written language skills of adolescent students. Often written language is the initial signal to a teacher that a student has language-learning problems. In order to understand a student's written language deficiencies, a speech-language pathologist needs to understand the stages in the scope of language development. Despite contrasting theories of development, written language continues to develop through the adolescent years. The four modes of language have linguistic features which relate, although, they involve different skill levels. A written language assessment procedure can provide a speech-language pathologist with examples of a student's language behaviors and organizational skills for comparison with other student's the same chronological age and cultural group. Written narratives are an example of a student's natural process for organizing the world around them and provide samples for analyzing their ability to create a unified text. 


\section{CHAPTER III}

\section{METHODS AND PROCEDURES}

This study was an elaboration of a study conducted by Brown (1990). Subject selection, subject criteria, data collection, and parent permisson were designed and administered by Brown. This investigator remained blind to the identities of the subjects.

\section{SUBJECTS}

\section{Experimental Subjects}

The language impaired students in the investigation were selected from the caseloads of speech-language pathologists in secondary schools in the Beaverton School District in Beaverton, Oregon. Twenty subjects were selected randomly from the students who met the following criteria:

1) language disorder (e.g., expressive or receptive language) identified in elementary school;

2) ongoing diagnosis of language impairment requiring language intervention services;

3) normal vision and hearing;

4) fine motor control as judged by the investigator to be adequate to complete the written language tasks;

5) between 15.0 and 19.0 years of age; 
6) attending a grade commensurate, within one year, of the student's chronological age;

7) previous diagnostic testing results, language sample, and teacher observations that indicate a mild to moderate language impairment;

8) no history or evidence of an organic problem and not on medication for a neurological disorder;

9) English as the primary language;

10) no known drug or related emotional problems; and

11) parent or guardian release form giving permission for participation in this study (Appendix B).

The mean age of the 12 males and 8 females in the language impaired group was 17.2 years, ranging from 16.0 to 18.6 years.

\section{Control Subjects}

Twenty students who attended schools in the same school district comprised the control group. Students included in the control group met the following criteria:

1) normal vision and hearing;

2) fine motor control as judged by the administrator to be adequate to complete the written language tasks;

3) between 15:0 and 19:0 years of age;

4) attending a grade commensurate with the student's chronological age;

5) no school record of having been referred for, or received, any type of educational or language support services; 
6) English as the primary language;

7) no known drug or related emotional problems; and

8) parent or guardian signed release form giving permission for participation in this study (Appendix B).

The mean of the 8 males and 12 females in the control group was 16.4 years, and age range of 15.8 to 18.4 years.

\section{INSTRUMENTATION}

This study used the analysis of cohesion described by Halliday and Hasan (1976) to score the written narratives. Each cohesive tie was identified as either a referent, substitution, ellipsis, conjunction, or lexical. See Appendix A for detailed definitions.

\section{PROCEDURES FOR THIS STUDY}

Written narratives were obtained from the experimental subjects in their Communication Skills classes taught by speechlanguage pathologists. Written narratives from the control subjects were obtained in their English classes taught by their regular certified classroom teacher. Task A (Personal Experience) and Task $B$ (Imaginary Event) were administered on different days to assure that students had a complete class period (55 minutes), to complete each task, if necessary. Half of the classes were administered Task A (PE) first, while the other half began with Task $B$. The subjects were given lined paper with printed directions at the top of the first 
page (Appendix $\mathrm{C}$ ). The administator then gave the same verbal instructions, "describe the way your day usually goes from beginning to end." If a subject made any inquiries or clarifications, the direction was paraphrased as, "describe the way your day is most of the time, from beginning to end."

Task B (IE) was obtained by providing the subjects with a printed story stem (Appendix D) originally written by Merritt and Liles (1989). Merritt and Liles wrote this story stem so it would "include a human protaganist and setting information and was designed to evoke images of an adventure involving a series of goal based events" (p. 439). The administrator instructed the subjects to read the story stem silently as the administrator read it aloud. They were instructed to "think about what might happen next and write a good story." At the completion of each task, the administrator read each narrative and asked the subjects for clarification of any illegible writing.

If the subject met the criteria for a control subject, and matched in age and sex to the experimental subjects, a release form (Appendix B) was then sent to the parent or guardian for permission to include the student's written narratives in the Brown (1990) research project.

\section{Investigator Reliability}

In order to assess investigator reliability in identifying cohesive texts, four written narratives, two from Task $A(P E)$ and two from Task $B(I E)$, were randomly selected from the experimental 
and control groups. These narratives were then given to two speechlanguage pathologists holding Certificates of Clinical

Competence (CCC) in Speech-Language Pathology by the American Speech-Language-Hearing Association. These reliability raters were responsible for identifying each cohesive device in the the selected written narratives, as previously described in Appendix A. Percentage of agreement for the interjudge reliability was .92 between the investigator and the two raters.

Prior to the actual reliability testing by the investigator a training session was held. The raters were given a description of this study, printed definitions of the five types of cohesion to be identified, with examples (Appendix A), scoring procedures (Appendix E), and two practice narratives (Appendix F). The raters read each text, then labeled each cohesive tie, with the assistance of Type of Cohesion (Appendix A). The raters and the investigator discussed their scoring after each practice narrative.

\section{DATA ANALYSIS}

Each original written narrative was transcribed verbatim into typescript to complete the analysis of cohesive texts. Raw scores for each type of cohesion were obtained for each written narrative from both tasks. The frequency of use of each component was computed and averaged for each group of subjects across tasks and among groups. A statistical analysis of total cohesive devices used and individual devices across tasks (PE and IE) and across groups 
(experimental and control) were completed using a two-way analysis of variance (ANOVA).

\section{LIMITATIONS OF THIS STUDY}

This investigator encountered a variety of limitations in analyzing this data. Due to the fact that this investigator remained blind to the subjects, he was unable to define more specifically their homogeneity. That is, how alike were the subjects in cultural influences, writing ability, socio-economic level, or educational experiences? 


\section{CHAPTER IV}

\section{RESULTS AND DISCUSSION}

\section{RESULTS}

The purpose of this study was to compare the written narrative texts of language impaired and normal adolescents. The results of this study were statistically analyzed by two-way analysis of variance (ANOVA) for each cohesive device measure to determine the effects of group (language impaired or normal), task (personal experience or imaginary event), and group/task interaction upon the five dependent variables (referent, substitution, ellipsis, conjunction, and lexical). This statistical analysis was used in order to minimize the number of $\mathrm{t}$-tests to reduce the probability of error. Table I displays the results of the ANOVA analysis, Table II displays the mean and standard deviations for the cohesive devices by group and Table III by task.

The first question addressed by this study was, are there differences in texts between language impaired and normal adolescents? Statistical analysis showed a significant group difference $(p<.05)$ between the two groups on all cohesive devices measured; referent, substitution, ellipsis, conjunction, and lexical.

The second question of this study was, do the written 
TABLE I

TWO-WAY ANALYSIS OF VARIANCE OF LANGUAGE IMPAIRED

AND NORMAL ADOLESCENTS' WRITTEN NARRATIVES

ON TASK A (PERSONAL EXPERIENCE) AND

TASK B (IMAGINARY EVENT)

\begin{tabular}{|c|c|c|c|c|c|}
\hline $\begin{array}{l}\text { COHESIVE SOURCE } \\
\text { DEVICE }\end{array}$ & $\begin{array}{l}\text { SUMOF } \\
\text { SQUARES }\end{array}$ & $\mathrm{DF}$ & $\begin{array}{l}\text { MEAN- } \\
\text { SQUARE }\end{array}$ & F-RATIO & $\begin{array}{l}\text { PROBA- } \\
\text { BILITY }\end{array}$ \\
\hline
\end{tabular}

\begin{tabular}{|c|c|c|c|c|c|c|}
\hline & GROUP & 1224.613 & 1 & 1224.613 & 5.191 & $.026^{*}$ \\
\hline \multirow[t]{3}{*}{ REFERENT } & TASK & 11688.613 & 1 & 11688.613 & 49.548 & $.000^{*}$ \\
\hline & GRP/TSK & 43.513 & 1 & 43.513 & .184 & .669 \\
\hline & ERROR & 17928.650 & 76 & 235.903 & & \\
\hline & GROUP & 49.613 & 1 & 49.613 & 13.679 & $.000^{*}$ \\
\hline \multirow[t]{4}{*}{ SUBSTITUTION } & TASK & 3.613 & 1 & 3.613 & .996 & .321 \\
\hline & GRP/TSK & 15.313 & 1 & 15.313 & 4.222 & $.043^{*}$ \\
\hline & EPFOR & 275.650 & 76 & 3.627 & & \\
\hline & GROUP & 66.613 & 1 & 66.613 & 10.000 & $.002^{*}$ \\
\hline \multirow[t]{4}{*}{ ELLIPSIS } & TASK & 13.613 & 1 & 13.613 & 2.044 & .157 \\
\hline & GRP/TSK & 5.513 & 1 & 5.513 & .828 & .366 \\
\hline & ERAOR & 506.250 & 76 & 6.661 & & \\
\hline & GROP & 605.000 & 1 & 605.000 & 4.944 & $.029^{\circ}$ \\
\hline \multirow[t]{4}{*}{ CONUUNCTION } & TASK & 204.800 & 1 & 204.800 & 1.674 & .200 \\
\hline & GRP $/ T S K$ & 470.450 & 1 & 470.450 & 3.845 & .054 \\
\hline & ERPOR & 9299.700 & 76 & 122.364 & & \\
\hline & GAOUP & 1288.013 & 1 & 1288.013 & 9.542 & $.003^{\circ}$ \\
\hline \multirow[t]{3}{*}{ LEXICAL } & TASK & 812.813 & 1 & 812.813 & 6.021 & $.016^{*}$ \\
\hline & GRP/TSK & 21.013 & 1 & 21.013 & .156 & .694 \\
\hline & ERPOR & 10259.150 & 76 & 134.989 & & \\
\hline
\end{tabular}

= Significant $(p<.05)$ 
TABLE \|

MEANS AND STANDARD DEVIATIONS FOR TASK A (PERSONAL EXPERIENCE) AND TASK B (IMAGINARY EXPERIENCE) COMBINED FOR THE LANGUAGE IMPAIRED AND NORMAL GROUPS

MEASURE

GROUP

MEAN

SD

Language Impaired

Referent

Normal $16.675-19.824$

$24.500 \quad 19.171$

Language Impaired

1.025

1.405

Substitution

Normal

2.600

2.362

Language Impaired

.975

3.174

Ellipsis

$\begin{array}{lll}\text { Normal } & 2.800 & 1.843\end{array}$

Language Impaired

$17.025 \quad 11.060$

Conjunction

Normal

$22.525 \quad 11.551$

Language Impaired

$12.000 \quad 12.784$

Lexical

Normal

$20.025 \quad 11.000$ 
TABLE III

MEANS AND STANDARD DEVIATIONS COMBINED FOR THE LANGUAGE IMPAIRED AND NORMAL GROUP FOR TASK A (PERSONAL EXPERIENCE) AND TASK B (IMAGINARY EVENT)

\section{MEASURE}

TASK

MEAN

$\mathrm{A}$
$\mathrm{A} .50$

Referent

$\begin{array}{lll}\text { B } & 32.67 & 20.20\end{array}$

A $2.02 \quad 2.34$

Substitution

$\begin{array}{lll}\text { B } & 1.60 & 1.79\end{array}$

A 1.47

Ellipsis

$\begin{array}{lll}\text { B } & 2.30 & 3.42\end{array}$

A $21.37-12.08$

Conjunction

$\begin{array}{lll}\text { B } & 18.17 & 10.95\end{array}$

$\begin{array}{lll}\text { A } & 12.82 & 8.89\end{array}$

Lexical

B

19.20

14.74 
narratives of a personal experience and an imaginary event produce different texts (cohesive devices) in language impaired and normal adolescents? Statistical analysis showed a significant difference $(p<.05)$ between the tasks for referent and lexical, and no significant difference indicated for substitution, ellipsis, and conjunction. One cohesive device, substitution, also showed an interaction effect between task and group. The language impaired group used more substitution devices on Task $B$ than Task $A$, and the normal group used more substitution devices on Task $A$ than Task B.

The significant differences were further analyzed with t-tests to determine if the group effects were different according to task and if the task effects were different according to group. The means and standard deviations by group and by task are shown in Figure 2 . Figures $3,4,5$, and 6 illustrate the comparisons between the two groups and between tasks. First, the group effects were compared using a t-test for independent means for each task individually (Tables IV and V). A significant difference was shown between all five cohesive devices on the personal experience task. However, there was no significant difference on any cohesive devices for the imaginary event. In all cases, the normal subjects performed better than the language impaired subjects.

Finally, the task effects were compared statistically with $\underline{\mathrm{t}}$ tests for dependent means for each group of subjects (Tables VI and VII). There was a significant difference between tasks on the referent measure for both groups, language impaired and normals. There was no significant difference between tasks for either group 
REFERENT

\begin{tabular}{|c|c|}
\hline TASK A & TASK B \\
\hline $\begin{array}{l}X=3.85 \\
S D=4.60\end{array}$ & $\begin{array}{l}x=29.5 \\
S D=20.95\end{array}$ \\
\hline $\begin{array}{l}x=13.15 \\
S D=10.3\end{array}$ & $\begin{array}{l}x=35.85 \\
S D=19.41\end{array}$ \\
\hline
\end{tabular}

SUBSTITUTION

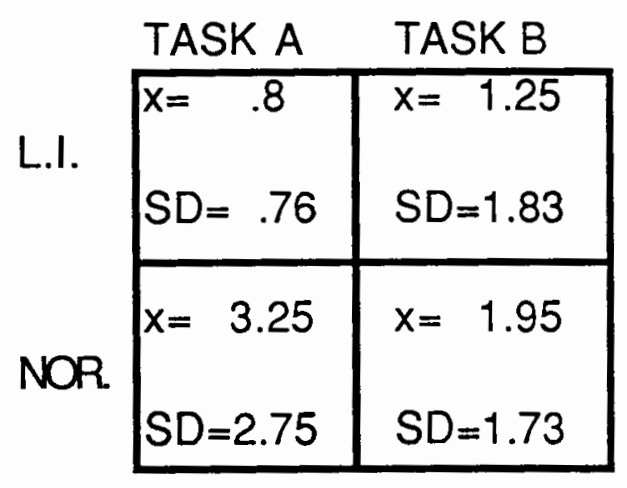

\section{ELLIPSIS}

\section{TASK A TASK B}

\begin{tabular}{|c|c|c|}
\hline L.I. & $\begin{array}{l}x=.3 \\
S D=.65\end{array}$ & $\begin{array}{l}x=1.65 \\
S D=4.39\end{array}$ \\
\hline & $\begin{array}{l}x=2.65 \\
S D=1.72\end{array}$ & $\begin{array}{l}x=2.95 \\
S D=1.98\end{array}$ \\
\hline
\end{tabular}

Figure 2. Means $(x)$ and standard deviations (SD) of language impaired and normal adolescents use of cohesive devices in written narratives for personal experiences (Task $A$ ) and imaginary events (Task B).
CONJUNCTION

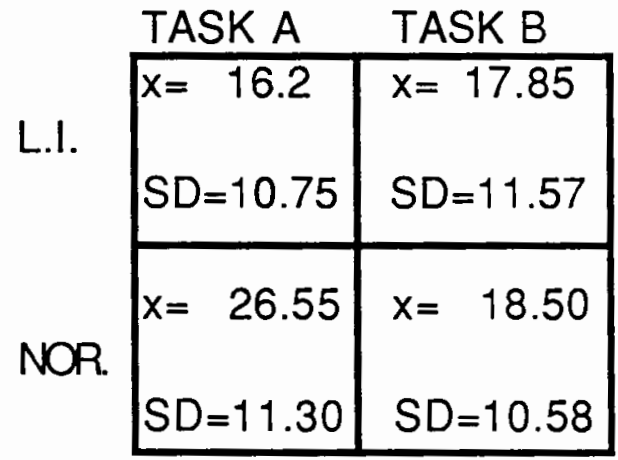

LEXICAL

TASK A TASK B

\begin{tabular}{l|l|l|} 
L.I. & $X=8.3$ & $X=15.7$ \\
& $S D=6.40$ & $S D=16.29$ \\
\hline$N O R$. & $X=17.35$ & $x=22.70$ \\
& $S D=8.84$ & $S D=12.45$ \\
\hline
\end{tabular}




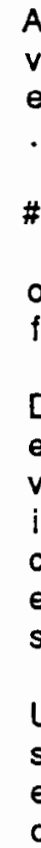

s
d

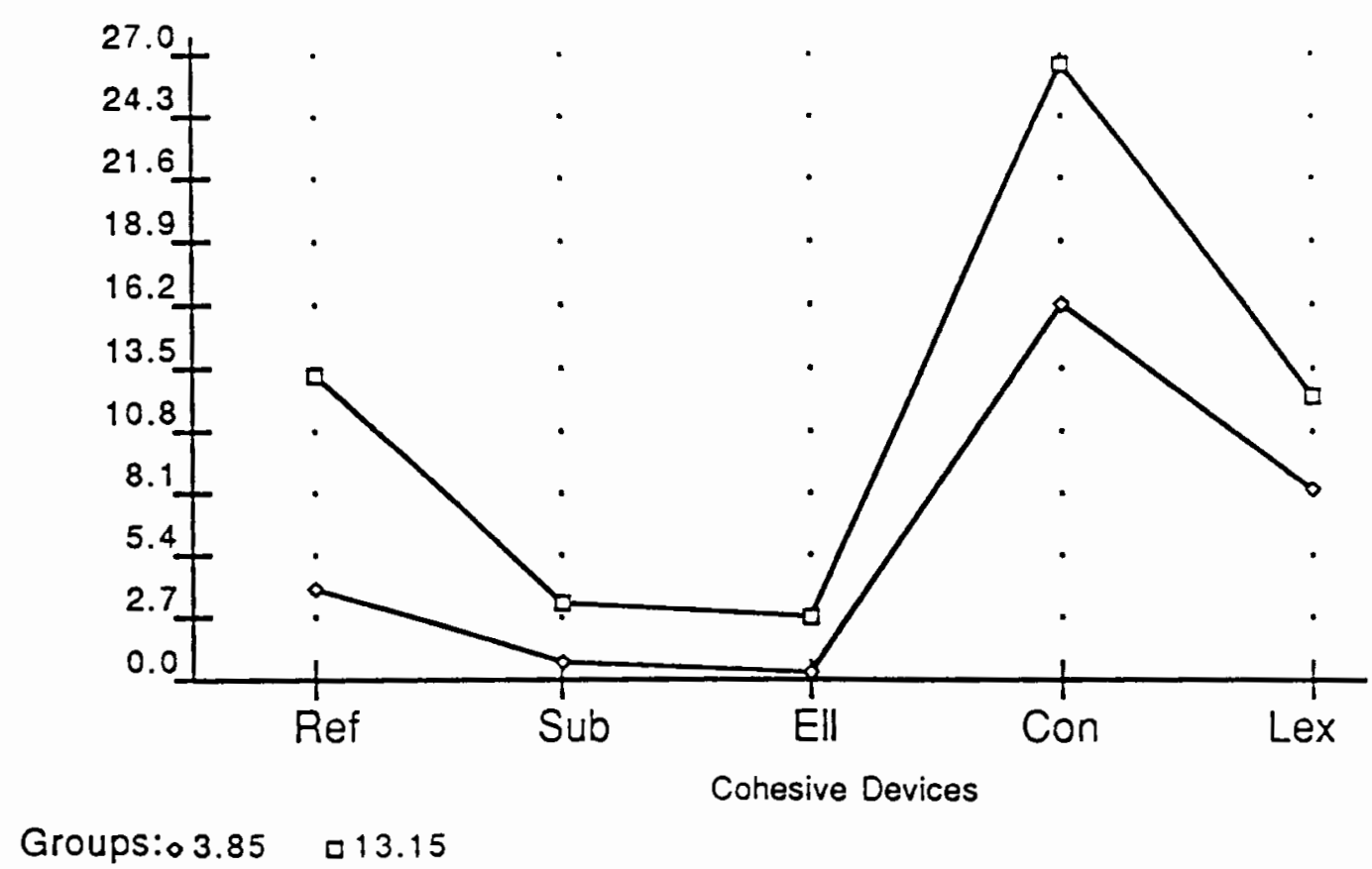

Figure 3. Comparison by Group-Task A (PE)
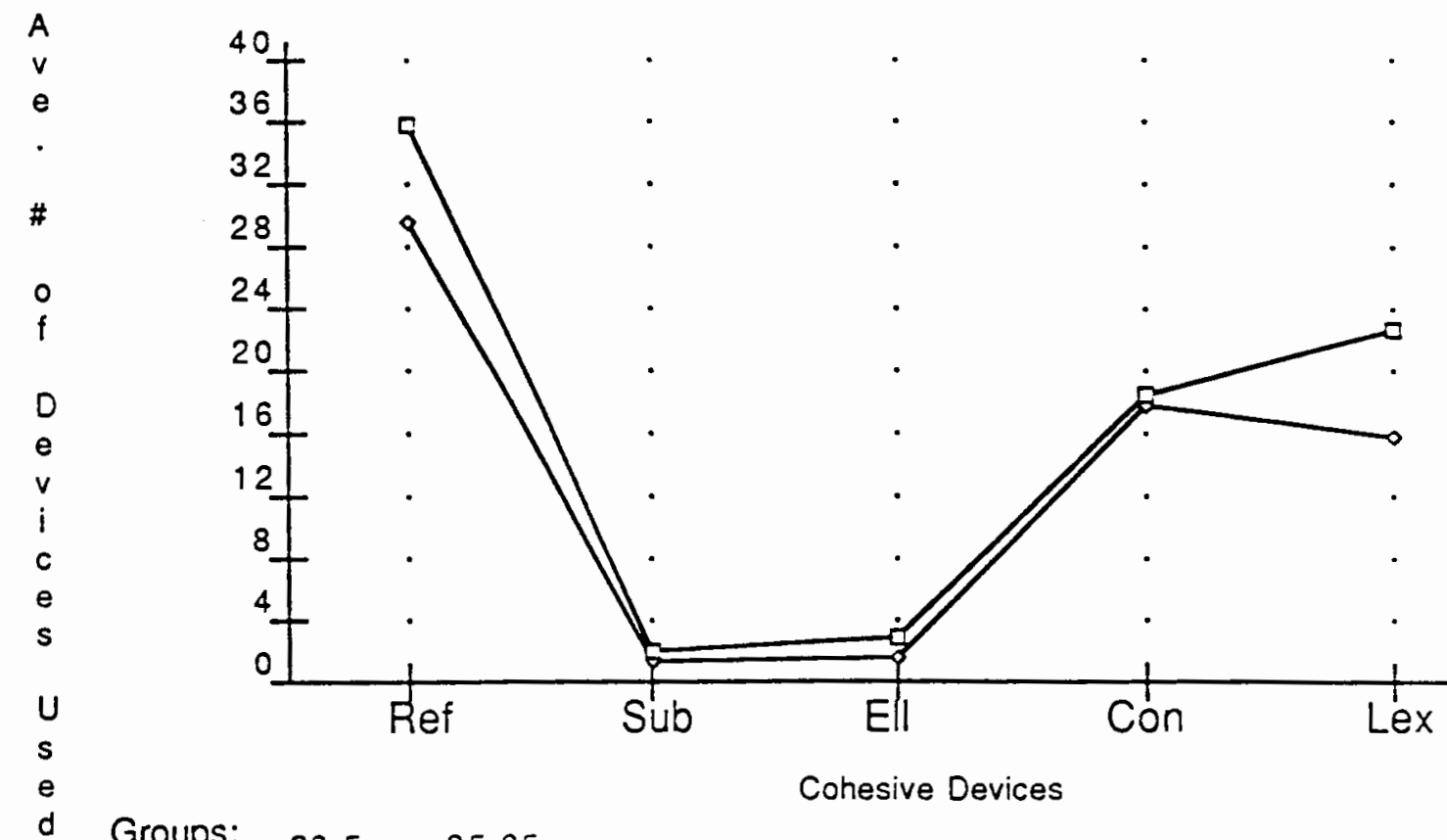

Cohesive Devices

Groups: $\circ 29.5 \quad \square 35.85$

Fiqure 4. Comparison by Group-Task B (IE) 


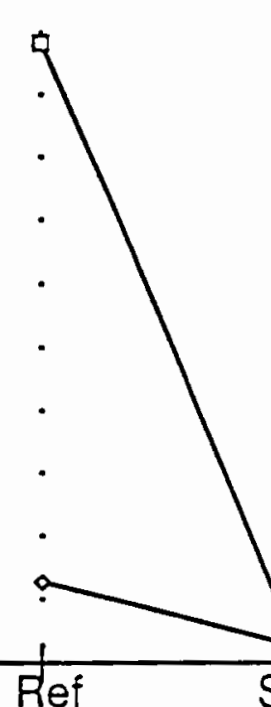

Tasks: $3.85 \quad \square 29.5$

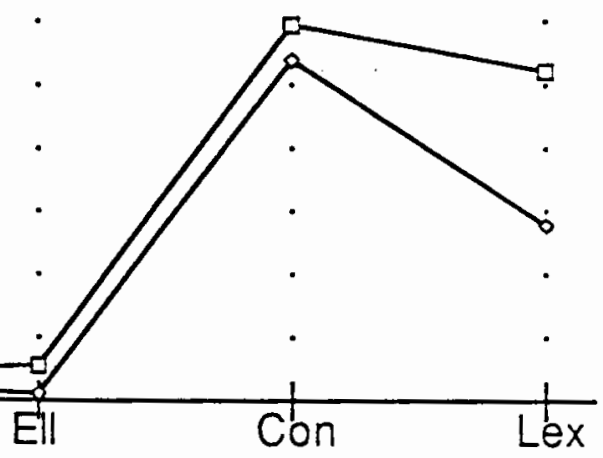

Cohesive Devices

Figure 5. Comparison of Tasks for Lang $\mathrm{lm}$
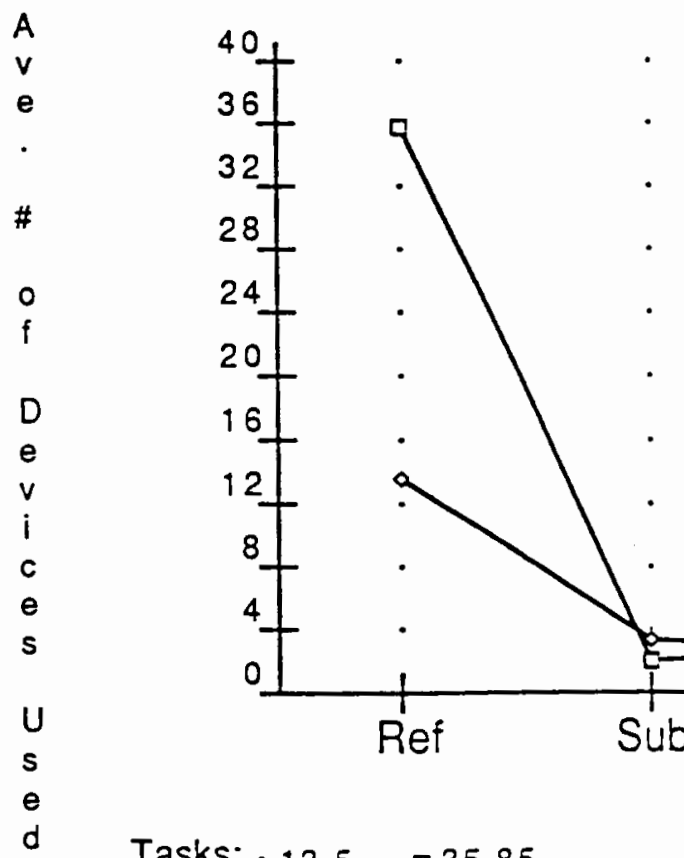

Tasks: $013.5 \quad 035.85$

Figure 6. Comparison of Tasks for Normals 
TABLE IV

\$-TEST RESULTS ON COHESIVE DEVICES FOUND TO BE SIGNIFICANT BY THE TWO-WAY ANOVA FOR THE LANGUAGE IMPAIRED AND NORMAL ADOLESCENT GROUPS FOR TASK A (PERSONAL EXPERIENCE)

MEASURE

GROUP MEAN

SD DF I-VALUE $p$

Language

Impaired

$3.85 \quad 4.60$

Referent

Normal $\quad 13.15 \quad 10.30$

$1 \quad 3.686$

$001^{*}$

Language

Impaired

Substitution

$.80 \quad .76$

Normal $\quad 3.25 \quad 2.75$

$1 \quad 3.837 \quad .000^{*}$

Language

Impaired $\quad .30 \quad .65$

Ellipsis

Normal $\quad 2.65 \quad 1.72$

$15.693 \quad .000^{*}$

\begin{tabular}{|c|c|c|c|c|c|c|}
\hline \multirow[b]{2}{*}{ Conjunction } & $\begin{array}{l}\text { Language } \\
\text { Impaired }\end{array}$ & 16.20 & 10.75 & \multirow[b]{2}{*}{1} & \multirow[b]{2}{*}{2.966} & \multirow[b]{2}{*}{$.005^{\star}$} \\
\hline & Normal & 26.55 & 11.30 & & & \\
\hline \multirow{2}{*}{ Lexical } & $\begin{array}{l}\text { Language } \\
\text { Impaired }\end{array}$ & 8.30 & 6.40 & \multirow{2}{*}{1} & \multirow{2}{*}{3.705} & \multirow{2}{*}{$.001^{*}$} \\
\hline & Normal & 17.35 & 8.84 & & & \\
\hline
\end{tabular}


TABLE V

§-TEST RESULTS ON COHESIVE DEVICES FOUND TO BE SIGNIFICANT BY THE TWO-WAY ANOVA FOR THE LANGUAGE IMPAIRED AND NORMAL ADOLESCENT GROUPS FOR TASK B (IMAGINARY EVENT)

MEASURE

GROUP

Referent

Impaired $29.50 \quad 20.95$

Normal $\quad 35.85 \quad 19.41$

.99

.327

$\begin{array}{lll}\text { Language } & & \\ \text { Impaired } & 1.25 & 1.83\end{array}$

Substitution

Normal $\quad 1.95 \quad 1.73$

$1 \quad 1.24$

.222

Language

Impaired $\quad 1.65 \quad 4.39$

Ellipsis

Normal $\quad 2.95 \quad 1.98$

1.20

.235

Language

Impaired $\quad 17.85 \quad 11.57$

Conjunction

Normal $\quad 18.50 \quad 10.58$

$\begin{array}{lll}1 & .18 & .854\end{array}$

Language

Impaired $\quad 15.70 \quad 16.29$

Lexical
Normal
22.70
12.45

* = Significant $(p \leq .05)$ 


\section{TABLE VI}

I-TEST RESULTS ON COHESIVE DEVICES FOUND TO BE SIGNIFICANT BY THE TWO-WAY ANOVA BETWEEN TASK A AND TASK B FOR THE LANGUAGE IMPAIRED GROUP

MEASURE TASK MEAN SD DF t-VALUE $p$

\begin{tabular}{|c|c|c|c|c|c|c|}
\hline \multirow[b]{2}{*}{ Referent } & A & 3.85 & 4.60 & \multirow[b]{2}{*}{1} & \multirow[b]{2}{*}{-5.346} & \multirow[b]{2}{*}{.000} \\
\hline & B & 29.50 & 20.95 & & & \\
\hline \multirow[b]{2}{*}{ Lexical } & $A$ & 8.30 & 6.40 & \multirow[b]{2}{*}{1} & \multirow[b]{2}{*}{-1.890} & \multirow[b]{2}{*}{.066} \\
\hline & B & 15.70 & 16.29 & & & \\
\hline
\end{tabular}

\section{TABLE VII}

t-TEST RESULTS ON COHESIVE DEVICES FOUND TO BE SIGNIFICANT BY THE TWO-WAY ANOVA BETWEEN TASK A AND TASK B FOR THE NORMAL ADOLESCENT GROUP

MEASURE TASK MEAN SD DF t-VALUE $\mathrm{p}$

\begin{tabular}{lcccccc} 
Referent & A & 13.15 & 10.30 & & & \\
& B & 35.85 & 19.41 & & & \\
\hline & A & 17.35 & 8.84 & & & \\
& B & 22.70 & 12.45 & & &
\end{tabular}

$\star=$ Significant $(p \leq .05)$ 
for the lexical measure; however, a trend toward significance was indicated with the language impaired group between tasks for the lexical measure.

\section{DISCUSSION}

As anticipated, the normal subjects performed significantly better on all five of the measures, i.e., referent, substitution, ellipsis, conjunction, and lexical. There was a significant difference between groups on all measures as the normal subjects scored better. This indicates that the language impaired subjects experienced difficulty with written language, as well as oral language.

The type of task did make a difference in performance for both groups. Referent was the only cohesive measure found to be statistically significant for both groups. There was a significant difference found between the language impaired and normal groups for Task A (PE) on all five measures. However, on Task B (IE), there was a significant difference found on only two measures, referent and lexical. These results indicate strong evidence to use the more stuctured task (PE) for diagnostic and prescriptive measures.

Both groups used a greater number of total devices on the imaginary event (Task $B$ ) than on the personal experience (Task $A$ ) narrative. The leading cohesive device used by both groups on the personal experience narrative (Task A) was conjunctions, and for the imaginary event (Task B) was referents. Thus, for this group, 
personal experience narratives must use more conjunctions to tie the message together, whereas the imaginary event tends to depend upon referents to tie its thoughts together. Neither task seemed to elicit many substitution or ellipsis as cohesive devices.

The following conclusions are drawn:

1. Language impaired adolescents used fewer cohesive devices than did the normal subjects when writing about personal experiences and imaginary events.

2. The narratives about imaginary events produced more cohesive devices than the ones about personal experiences.

3. The cohesive device analysis is a useful approach to assess written narratives of high school language impaired students, as it provides both diagnostic and prescriptive information about their written language skills. 


\section{CHAPTER V}

\section{SUMMARY AND IMPLICATIONS}

\section{SUMMARY}

Classroom teachers frequently refer adolescents to speechlanguage pathologists for language skill evaluations. Many of the traditional evaluation tools of the speech-language pathologist focus on the student's oral language skills. The first indication to the classroom teacher that there may be a language problem, however, is usually from the student's written classwork. Very few written language assessment tools are available which give the speech-language pathologist information regarding linguistic units which can be viewed as communication acts. This paper focuses on one particular discourse unit - the written narrative. Narratives are a natural form of thought and demonstrate how a person organizes and views the world around them. Narratives can be analyzed from the perspective of their "texts," how the writer links individual sentences together to create a cohesive discourse.

The purpose of this study was to compare the written narratives of language impaired and normal adolescents. Two questions were addressed in this study. First, are there differences in texts between language impaired and normal adolescents? And 
second, do the written narratives of a personal experience and imaginary event produce different texts in language impaired and normal adolescents?

Forty high school students comprised the two groups of subjects with 20 in each group. The experimental group included students who had been diagnosed as language impaired and who were receiving speech and language services. The control group included 20 students who were normal in language skills, i.e., enrolled in regular classrooms and not on IEPs. All subjects were enrolled in Beaverton School District high schools. The subjects were instructed to write two narratives, one about a personal experience, i.e., how your day usually goes, and the other about an imaginary event, with the starter "One day a plane was flying through the towering mountains." No time limit was set for the completion of the tasks, students could take the whole class period to complete the tasks if needed. This study used the analysis of cohesion described by Halliday and Hasan (1976) to score the written narratives. Five types of cohesive devices were measured: referents, substitutions, ellipsis, conjunctions, and lexicals. Scores were the total number of each cohesive device used for each written narrative for each subject.

The results of both questions were statistically analyzed through the use of a two-way analysis of variance (ANOVA) for each cohesive device to determine the effects of group (language impaired or normal), task (personal experience or imaginary event), and group/task interaction upon the five dependent variables 
(referent, substitution, ellipsis, conjunction, and lexical). The results indicated that there was a significant difference $(p \leq .05)$ between the groups on all five cohesive device measures, and a significant difference of task on referent and lexical only. Only one cohesive device, i.e., substitution, showed an interaction effect between task and group. Both groups used more cohesive devices on the imaginary event than the personal experience task.

The significant differences were further analyzed with $\mathrm{t}$ tests to determine if the group effects were different according to task and if the task effects were different according to group. First, the group effects showed a significant difference on all cohesive device measures for the personal experience task, but not significant on any for the imaginary event. Secondly, the task effects were significant for the normal and language impaired subjects for the referent device only. In all cases the normal subjects performed better than the language impaired subjects.

The results of the narrative analysis revealed that there is a significant difference between the two groups of subjects, with the normal subjects performing better. Also there was a significant difference between the performance on the two different tasks, with more cohesive devices used on the imaginary event task than the personal experience task. 


\section{CLINICAL IMPLICATIONS}

The results of this study indicate that the language impaired students did not perform as well as the normal students, specifically on the personal experience narrative task. Since there is a significant difference between the two groups, it appears that written narrative analysis of cohesion would be helpful in identifying students with written language deficits, and provide some diagnostic and prescriptive information for describing and planning remediation for the deficit. From this description the speech-language pathologist knows the strengths of the student and can begin intervention from this area, working toward the deficit.

\section{RESEARCH IMPLICATIONS}

In order to support the above statement that normal students perform better than language impaired students, more narratives need to be analyzed using different subjects from different communities. Also, the length of the student's narratives might need to become more controlled, as they varied from $1 / 2$ to three pages which might have affected the scoring results, although each subject was allotted the same amount of time. The use of percentages of cohesive device types or ratio of cohesive devices to number of sentences might have been a better measure. 
Another area for research on this topic would be to compare these results to written narratives of other groups, e.g., seriously emotionally disturbed students, good writers vs. poor writers, or other age groups, e.g., language impaired elementary, primary, and junior high school students to examine possible developmental trends. Specifically defining these groups to create better homogeneity is recommended. Further research on this topic would not only benefit the analysis of narratives for diagnostic purposes, but might also assist in developing the design for an intervention program. 


\section{REFERENCES}

Alley, G. \& Deschler, D. (1979). Teaching the learning disabled adolescent: Strategies and Methods. Denver, CO: Love.

Bloom, L. \& Lahey, M. (1978). Language development and language disorders. NY: Wiley \& Sons.

Britton, J. (1978). The composing processes and the functions of writing. In C.R. Cooper, and L. Odell (Eds.), Research on composing: Points of departure. Urbana, IL: National Council of Teachers of English.

Brossell, G. (1986). Current research and unanswered questions in writing assessment. In K.L. Greenberg, H.S. Wiener, \& R.A. Donovan (Eds.), Writing assessment: issues and strategies. New York \& London: Longman.

Brown, A. (1990). Written Narratives of Learning Disordered and Normal Adolescence on Two Tasks, Unpublished master's thesis, Portland State University, Portland, OR.

Cambourne, B. (1988). The Whole Story: Natural Learning and the Acquisition of literacy in the Classroom. Auckland: Ashton Scholastic.

Chafe, W. (1982). Integration and involvement in speaking, writing, and oral literacy. In D. Tannen (Ed.), Spoken and written language. New Jersey: Ablex.

Chafe, W. (1985). Linguistic differences produced by the differences between speaking and writing. In D.R. Olson, $\mathrm{N}$. Torrance, \& S. Hildyard (Eds.), Literacy, language, and learning. NY: Cambridge University Press. 
Chafe, W. \& Danielewicz, J. (1987). Properties of spoken and written language. In R. Horowitz \& S.J. Samuels (Eds.), Comprehending oral and written language. San Diego, CA: Academic Press.

Conlan, G. (1986). "Objective" measures of writing ability. In K.L. Greenberg, H.S. Wiener, \& R.A. Donovan (Eds.), Writing assessment: issues and strategies. New York \& London: Longman.

Dagenais, D.J. \& Beadle, K.R. (1984). Written language: when and where to begin. Topic in Language Disorders, 3, 59-85.

Gajewski, N. and Mayo, P. (1989). SSS: Social Skills Stategies, Eau Claire, WI: Thinking Publications.

Halliday, M. \& Hasan, R. (1976). Cohesion in English. London: Longman.

Heath, S. (1983). Ways with words: Language, life and work in communities and classrooms. NY: Cambridge University Press.

Horowitz, R. \& Samuels, S.J. (1987). Comprehending oral and written language. San Diego, CA: Academic Press.

Hoskins, B. (1990). Language and literacy: Participating in the conversation. Topics in Language Disorders, 2, 46-62.

Isaason, S. (1985). Assessing Written Language Skills. In C. Simon (Ed.) Communication Skills and Classroom Success: Assessment of Language-Learning Disabled Students. San Diego: College-Hill Press.

Johnston, J.R. (1982). Narratives: A new look at communication problems in older language-disordered children. Language. Speech and Hearing Services in the Schools, 13, 144-155.

Lahey, M. (1988). Language disorders and language development. NY: MacMillan. 
Leonard, L.B., Prutting, C.A., Perozzi, J.A., \& Berkley, R.K. (1978).

Nonstandardized approaches to the assessment of

language behaviors. Asha, 5, 371-379.

Lloyd-Jones, R. (1977). Primary trait scoring. In C.R. Cooper and L. Odell (Eds.), Evaluating writing: Describing measuring. judging (pp. 33-66). Buffalo, NY: National Council of Teachers of English.

Loban, W. (1976). Language Development: Kindergarten through Grade Twelve, Urbana, IL: National Council of Teachers of English.

Merritt, D. \& Liles, B. (1989). Narrative analysis: clinical applications of story generation and story retelling. Journal of Speech and Hearing Disorders, 3, 438-445.

Moran, M. (1987). Epilogue. Topics in Lanquage Disorders, 4, 86-89.

Peterson, H.A. and Marquardt, T.P. (1981). Appraisal and Diagnosis:

Speech and Lanquage Disorders, Englewood Cliffs, N.J.:

Prentice-Hall, Inc.

Phelps-Gunn, T. \& Phelps-Teraski, D. (1982). Written Language Instruction: Theory and remediation. Rockville, MD: Aspen Systems.

Poplin, M. (1983). Assessing developmental writing abilities. Topics inLearning \& Learning Disabilities, 3, 63-75.

Rubin, D. (1987). Divergence and convergence between oral and written communication. Topics in Lanquage Disorders, 4, $1-18$.

Schumacker, J. \& Deschler, D. (1984). Setting demand variables: a major factor in program planning for the LD adolescent. Topics in LanguageDisorders, 2, 22-40. 
U.S. Department of Education (1986). What Works: Research about teaching and learning, Washington, D.C.: U.S. Department of Education.

Vallecorsa, A.L. and Garriss, E. (1990). Story composition skills of middle-grade students with learning disabilities.

Exceptional Children, 57, 1, 48-54.

Weiss, C.E. and Lillywhite, H.S. (1981). Communicative Disorders: Prevention and Early Intervention, St. Louis: C.V. Mosby Co.

Westby, C.E., Van Dongen, R., \& Maggart, Z. (1989). Assessing narrative competence. Seminars in Speech and Language, 1 , 63-76. 
APPENDIXA

TYPES OF COHESION 


\section{APPENDIX A \\ TYPES OF COHESION \\ (Halliday and Hasan, 1976)}

\section{REFERENCE}

1. Pronominals
a. singular, masculine
he, him, his
b. singular, feminine
she, her, hers
c. singular, neuter
it, its
d. plural
they, them, their, theirs

2. Demonstratives and definite article
a. demonstrative, near
b. demonstrative, far
c. definite article

3. Comparatives (not complete lists)
a. identity
b. similarity
c. difference(ie: non-identity and dissimilarity)
d. comparison, quantity
e. comparison, quality
this/these, here that, those, there, then the

eg: same, identical, exact

eg: similar(ly), such

eg: different, other, else, additional

eg: more, less, as many; ordinals eg: as + adjective; comparatives and superlatives

\section{SUBSTITUTION}

1. Nominal substitutes
a. for noun Head
b. for nominal Complement
onelones
c. for Attribute
the same
so

2. Verbal substitutes
a. for verb
do, be, have
b. for process
do the same/likewise
c. for proposition do so, be so
d. verbal reference
do it/that, be it/that

3. Clausal substitutes
a. positive
so
b. negative 


\section{ELLIPSIS}

1. Nominal ellipsis

a. Numerative as Head

1. ordinal

2. cardinal

3. indefinite

b. Epithet as Head

1. superlative

2. Verbal ellipsis

2. comparative

a. lexical ellipsis ('from right')

1. total (all items omitted except first operator)

2. partial (lexical verb only omitted)

b. operator ellipsis ('from left')

1. total (all items omitted except lexical verb)

3. Clausal ellipsis

2. partial (first operator only omitted)

a. general ellipsis of the clause (all elements but one omitted)

1. WH- question or answer

2. yes/no question or answer

\section{CONJUNCTION}

1. Additive

a. simple

1. additive

and, and also

2. negative

nor, and ... not

3. alternative

or, or else

b. complex, emphatic

1. additive

furthermore, add to that

2. alternate

c. complex, de-emphatic

alternatively

d. apposition

1. expository

by the way

2. exemplificatory

e. comparison

1. similar

2. dissimilar

that is, in other words eg, thus

likewise, in the same way on the other hand, by contrast 
2. Adversative

a. adversative 'proper'

1. simple

2. + 'and'

3. emphatic

b. contrastive

1. avowel

2. simple

3. emphatic

c. correction

1. of meaning

2. of wording

d. dismissal

1. closed

3. Causal

2. open-ended

a. general

1. simple

2. emphatic

b. specific

1. reason

2. result

3. purpose

c. reversed causal

d. causal, specific

1. reason

2. result

3. purpose

e. conditional

1. simple

2. emphatic

3. generalized

4. reversed polarity

so, then, therefore consequently

on account of this in consequence

with this in mind

for, because

it follows

arising out of this

to this end

then

in that case, in such an event

under the circumstances

otherwise, under other circumstances 
f. respective

1. direct

2. reversed polarity

4. Temporal

1. simple
a. sequential
b. simultaneous
c. preceding

2. conclusive

3. correlatives

a. sequential

b. conclusive

4. complex

a. immediate

b. interrupted

c. repetitive

d. specific

e. durative

f. terminal

5. internal temporal
a. sequential

b. conclusive

6. correlatives

a. sequential

b. conclusive

7. here and now
a. past
b. present
c. future

8. summary

a. summarizing

b. resumptive

9. Other ('continuative') in this respect, here otherwise, apart from this, in other respects

then, next, afterwards just then before that, hitherto, in the end

first . . then

at first/originally/

formerly . . ./finally/now

at once

soon

next time, again

next day

meanwhile

until then

at this moment

then, next

finally, conclusion

first . . next

in the first place...

to conclude with

up to now

at this point

from now on

to sum up

to resume

now, of course, well,

anyway, surely, after all 


\section{LEXICAL}
A. Same item
B. Synonym or near synonym
C. Superordinate
D. 'General' item
E. Collocation 
APPENDIX B

LETTER TO PARENTS FOR INFORMED CONSENT 


\section{LETTERS TO PARENTS FOR INFORMED CONSENT}

Dear

and

I am a Speech-Language Pathologist in the Beaverton School District. I am currently conducting a research project to complete a Master's Degree at Portland State University under the supervision of Mary Gordon. I am looking for differences and simlarities in the way adolescents' compose a written narrative when asked to write about a personal experience and an imaginary experience.

This study can be accomplished by giving permission for me to analyze two written assignments that were given in an English class.

name will be kept confidential, and will not be used when reporting the results.

Choosing to participate will not affect your child's grade in their English course.

Please read the form below, indicate your approval and willingness to participate in this study, and return the form to me as soon as possible in the envelope provided. An extra copy has been included for you to keep. Please call me if you have any questions (641-7224). Thank you for your cooperation.

Sincerely,

Antigone $\mathrm{H}$. Brown

I hereby give permission for my child, the study on adolescents' written narratives, and my child has agreed to serve as a subject in the research project. We understand that the study will involve an analysis of two written assignments that were completed in an English class. We understand that we may withdraw our permission at any time without jeopardizing my course grade or my relationship with Portland State University.

Parent/Guardian Signature

Date

Student's Signature

Date

If you experience problems that are the result of your participation in this study, please contact the secretary of Human Subjects Research Review Committee, Office of Grants and Contracts, 303 Cramer Hall, Portland State Univerity, 725-3417. 


\section{APPENDIXC}

\section{PERSONAL EXPERIENCE FORM - EXAMPLE}


DESCRIBE THE WAY YOUR DAY USUALLY GOES, FROM BEGINNING TO END: 


\section{APPENDIX D}

IMAGINARY EVENT FORM - EXAMPLE 
One day a pilot was flying through the towering mountains 
APPENDIXE

ANALYSIS OF COHESION SCORING PROCEDURES 


\section{ANALYSIS OF COHESION SCORING PROCEDURES}

1. Read each narrative in its entirety and then separate it into sentences. A statement is considered a sentence if it is ended by one of the following punctuation marks; period, question mark, exclamation point.

2. Read each sentence and underline any cohesive devices which are identified.

3. Below each underlined device place the following code letter; "R" if it is a Referent, "S" if it is Substitution, "E" if it is an Ellipsis, "C" if it is a Conjunction, and "L" if it is Lexical cohesion. One may use Appendix B (Types of Cohesion) to assist them in identifying types of cohesion.

4. There may be more than one cohesive device per sentence.

5. Following scoring of the narrative, add the total of each device and a grand total of devices used and record at the top of the paper. For example, "R - 10, S - 3, E - 7, C- 4, L - 15, Total - 39." This would indicate that there were 10 Referents, 3 Substitutions, 7 Ellipsi, 4 Conjunctions, and 17 Lexical cohesive devices providing for a grand total of 39 devices used.

6. Indicate whether the narrative was a personal experience (PE) or an imaginary event (IE) by placing the appropriate code following the grand total. 


\section{APPENDIX $F$}

TRAINING MATERIAL FOR INVESTIGATOR RELIABILITY 


\section{APPENDIX F \\ TRAINING MATERIAL FOR INVESTIGATOR RELIABILITY}

\section{Introduction}

Many of the assessment tools of written language available to Speech-Language Pathologists only provide diagnostic information at the word or sentence level. In my investigation of written language $I$ intend to focus on the entire written narrative and what devices adolescents utilize to tie their sentences together, to create a unified whole. Specifically, I am looking at five distinct devices used to analyze texts. The purpose of this study is to examine and compare the written narratives of adolescents, to determine; 1) Are there differences between the narratives of normal adolescents and language-impaired adolescents, and 2) Do the written narratives of a personal experience and an imaginary event produce different texts in the two groups.

\section{Cohesive Devices}

Two linguists, Halladay and Hasan, developed a procedure for analyzing the cohesiveness of texts. They divided the cohesive devices into five groups; reference, substitution, ellipsis, conjunction, and lexical. The following is a brief description and some examples of each cohesive device. If you have any questions regarding the definitions of words or clarifications in their useage, please feel free to stop me and ask.

\section{REFERENCE}

This device is the relation between a component of the text and something else for interpretation. This relationship can either be through identification or comparison with the other element. It is a relation in the meaning of the sentence. In English they are personal pronouns, demonstratives and comparatives. 
Examples:

1.Three blind mice, three blind mice.

See how they run! See howthey run!

(They is the personal pronoun referring to the 'three blind mice.')

2.After the long overtime hours away from his family, George decided he wanted no more of this.

(This is the demonstrative referring to the 'long overtime hours away from his family.')

3.The Lions chose Larry to be their quarterback, as accurate a passer there never was.

(As accurate is a comparative referring to 'Larry' the quarterback.)

Practice: Find the referent in the second sentence.

The oranges were not as tasty this season. They did not taste sweet.

\section{SUBSTITUTION}

Substitution can be thought of as the replacement of one item for another.

The item that is substituted has the same structural function as the item it replaced. It is a relation in the wording of the sentence.

Examples:

1. My pencil is too blunt. I must get a sharper one.

(One substitutes for 'pencil.')

2. Do you think Steve already knows? - I think everyone does . (Does substitutes for 'knows.')

Practice: Find the substitution in the second sentence. Nancy achieved the highest score of all. She is one of the smartest girls at school. 


\section{ELLIPSIS}

This device is similar to substitution, however it is 'substitution by zero.'

It is could be explained as 'that which is left unsaid' or 'something that is understood.'

\section{Examples:}

1. Steve brought a baseball, and Bill golf clubs.

(It is understood that Bill brought the golf clubs.)

2. Would you like to see another video? I have seven more.

(It is presupposed that they have seven more videos .)

Practice: Find the ellipsis in the second sentence.

Bill and Kathy brought a fruit salad. Steve and Joan rolls.

\section{CONJUNCTION}

Conjunctive devices express intent that presuppose the presence of other elements in the narrative. This device provides a way in which what is to follow is efficiently tied to what took place before.

\section{Examples:}

1. They played a game. Afterwards, it rained.

(Afterwards is the underlying semantic relation presupposing the element of time.)

2. She fell asleep, in spite of her discomfort.

(In spite, presupposes the element of adversity.)

3. She looked at the Queen .... Alice rubbed her eyes, and looked again.

(The presupposed item for again is 'looked at the Queen.') 
Practice: Find the conjunction in the second sentence.

They were glad to be moving back to Oregon. That is if Dan could find a job.

\section{LEXICAL}

This device is determined by the selection of vocabulary in a discourse.

Lexical cohesion is established when a noun is used, in a non -defining manner to make reference to a prior noun, either through reiteration or collocation. Reiteration may take place by the occurrence of repetition or the use of a synonym in the context of reference.

\section{Examples:}

1. The nail box was not difficult to assemble. We had a base, and then an end, and the two sides, with a piece of wood across the middle.

(The 'box' is the presupposed item for base, end, and sides .)

2. I have just read Dan's essay. The whole thing is very well organized.

(Thing refers to Dan's essay.)

Practice: Find the lexical item in the second sentence.

Steve designed a computer at work. The system is faster than any other on the market.

\section{Analysis of Cohesion Scoring Procedures}

During this step, read along silently as I read the Analysis of Cohesion Scoring Procedures from Appendix $E$. If you have any question regarding the procedures feel free to ask. 


\section{Practice}

Below are two narratives we will use to practice scoring. Please use Appendix $E$ (Analysis of Cohesion Scoring Procedures) and Appendix A (Types of Cohesion) to assist you. When you are finished completing the first narrative we will stop, compare, and discuss our scoring. Then we will procede to the second narrative and score, compare, and discuss it in the same manner. Any questions? Let's begin.

\section{Practice Narrative \#1:}

1. Jim had been a truck driver for many years.

2. He loved the road and took pride in being a very careful driver.

3. One day, after it had been snowing for several hours he came upon

a snowslide blocking all of the lanes of the highway.

4. He quickly stepped on the air brakes and stopped just short of the snow on the pavement.

5. The sound of the sharp screech of the brakes loosened some snow on the ridge above the roadway causing a major avalanche.

6. Jim and his rig were buried beneath several tons of snow for a couple of hours before the rescue crews were able to free him and provide medical treatment.

7. He survived this winter road hazard to drive truck another eight years until he retired. 


\section{Practice Narrative \#2:}

1. My day usually begins with the alarm startling me from a sound sleep.

2. I head for the shower then I let the dog out.

3. After getting dressed for school, I read the sports page while trying to finish off my Wheaties.

4. Before I head out the door to catch the school bus, I grab my backpack and borrow some lunch money from my mother's purse.

5. Then I take big yellow number 23 to the doors of East High where 1 begin another morning counting the minutes to lunch where I will see the sweetheart, Lisa.

Scoring for Investigator Reliability Study

To determine investigator reliability in identifying cohesive devices, four randomly selected written naratives from each group, two from Task A (PE) and two from Task $B$ (IE). You will be responsible for identifying the cohesive devices in each sentence, as previously described in Appendix B.

When you have completed scoring your narratives I will calculate the percentage of agreement for interjudge reliability between this researcher and the two raters. 


\section{APPENDIXG}

HUMAN SUBJECTS INITIAL REVIEW 


\section{HUMAN SUBJECTS INTIAL REVIEW}

\section{PROJECT TITLE: Written Narratives of Adolescents}

The purpose of this study is to compare the written narratives of language impaired adolescents with those of normal adolescents. Also a comparison will be made of written narratives about personal experiences (Task $A$ ) and written narratives of imaginary events(Task B), i.e., one that had not been personally experienced. Each narrative task will be analyzed using a cohesive text analysis. An analysis of the total cohesive text devices used and individual cohesive text devices across tasks and across groups will be completed using a MANOVA. The frequency of use of each component will be computed for each group of subjects across tasks and across groups. Additionally, a MANOVA will be used to determine if there is an order effect for either group of subjects.

This proposed research is not being conducted pursuant to a contract or grant.

\section{EXEMPTION CLAIMS. 5.}

This research project involves the study of existing data collected by a researcher, Antigone Brown who received approval of her HSIR by the Portland State University Office of Graduate Studies and Research. This researcher will only know the subjects by number identifiers.

\section{SUBJECT RECRUITMENT}

Language impaired students who attended secondary schools in the Beaverton School District, Beaverton, Oregon, and were enrolled in Communication Skills classes taught by speechlanguage pathologists were given specific writing assignments in their classes. The original investigator called the parent(s) of the students who met the subject criteria in order to inform them about the study. The original investigator then sent a letter of consent to the student and his/her parent(s) for permission to use the student's narratives. 
The control subjects were recruited from students attending secondary schools in the same school district and were enrolled in regular education English classes. These students were given writing assignments in their English classes identical to the assignments given to the language-impaired population. The original investigator then called the parent(s) of the students who met the subject criteria in order to inform them about the study. The original investigator then sent a letter to the student and his/her parent(s) for permission to use the student's narratives.

\section{INFORMED, VOLUNTARY CONSENTIN WRITING}

The language-impaired students in this investigation were selected from the caseloads of speech-language pathologists in secondary schools in the Beaverton School District. Twenty subjects were selected who met the following criteria:

1. history of language disorder diagnosed in elementary school;

2. ongoing diagnosis of language impairment requiring language management services;

3. normal vision and hearing;

4. fine motor control as judged by the investigator to be adequate to complete written language tasks;

5. between 14.0 and 18.0 years of age;

6. attending a grade commensurate, within one year, of the student's chronological age;

7. previous diagnostic testing results, language sample, and teacher observations that indicate a mild to moderate language impairment;

8. no history or evidence of an organic problem and not on medication for a neurological disorder;

9. English as the primary language;

10. no known drug or related emotional problems; and

11. parent or guardian signed release form giving permission for participation in this study.

Twenty subjects who attended secondary schools in the same school district as the language-impaired subjects will comprise the control group. The control students will be 
matched with the language-impaired students by age $( \pm 6$ months) and sex. Students included in the control group will meet the following criteria:

1. normal hearing and vision;

2. attending a grade commensurate with the student's chronological age;

3. no school record of having been referred for, or received, any type of educational or language support services;

4. parent or guardian release giving permission for participation in this study;

5. English, as the primary language; and

6. no known drug or related emotional problems.

Informed consent for both groups of subjects was obtained by mailing a letter of consent addressed to both the parent(s) and students. Included were a description of the study and a statement that their participation was not required. Two copies were sent; one to be signed and returned to the researcher, the other for their own records. A self-addressed stamped envelope was included for returning the consent form to the researcher. This process was completed by the original investigator, A. Brown.

\section{FIRST PERSON SCENARIO.}

Not applicable.

\section{POTENTIAL RISKS AND SAFEGUARDS.}

There are no known physical, social, economic, or other risks to the subjects. Anxiety may have been experienced by some students, but it was of the type that is normally experienced during the completion of any regular classroom assignment. The administrators administered these tasks in the same manner that they administered any other daily classroom assignments. 


\section{POTENTIAL BENEFITS OF THE PROPOSED STUDY.}

Potential benefits of this proposed study would be that the results may provide norm-referenced data on the written narratives of adolescents to assist in the identification and development of treatment programs for language-impaired students.

\section{RECORDS AND DISTRIBUTION.}

Following confirmation of subjects' age and grade level, their written narratives were assigned a number. This researcher will not know the identities of the subjects and will refer to them only by that number.

Names of subjects' were discarded by the original investigator. 


\section{APPENDIXH}

\section{EXAMPLES OF SCORED NARRATIVES}


O6LANGB 43090 R-31 S-1 E- $0 \quad C-16 \quad L-10$ Total-58

One day, a young pilot was flying through the towering mountains $\frac{\text { when }}{c} \frac{\text { he }}{R}$ heard a noise from the ingen, it sounded like a shotgun.

$\frac{H e}{R}$ looked out bolth sides of the plane windows $\frac{\text { and found that the right }}{C}$ engion on the plane had a blow out.

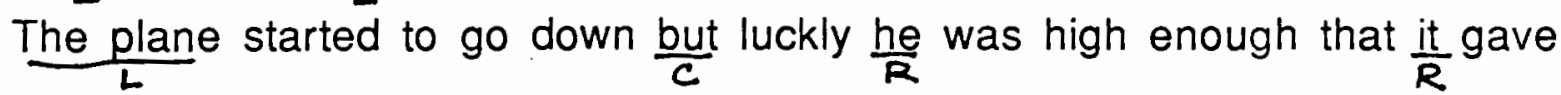
$\frac{h i m}{R}$ time to think of what he should $\frac{\text { do }}{S}$ first.

$\frac{H e}{R}$ thought that he should try to fly the plane to a small lake that was about 20 miles to the left of $\frac{h i s}{R}$ air cruise, and try to land the plane in the

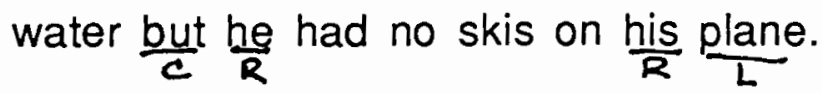

$\frac{S o}{C} \frac{h e}{R}$ decided to see as far as he could on the flight path that he was on because he new that he was going to crash eney way and $\frac{i t}{R} \frac{}{R}$ would be easeyer for someone to find $\frac{h i m}{R}$.

$\frac{H e}{R}$ soon crashed on the bottom of a mountain $\frac{\text { and }}{C}$ was not hurt.

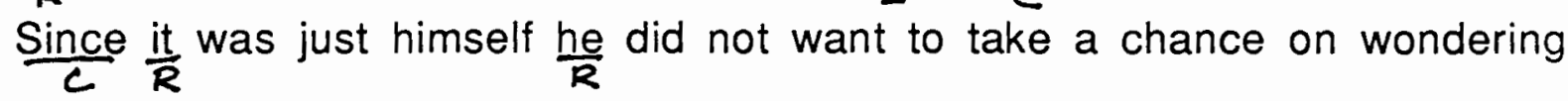
off $\frac{\text { and }}{C}$ not being found, $\frac{S O}{C} \frac{h e}{R}$ stayed by the plane $\frac{\text { and }}{C}$ got every thing that $\frac{h e}{R}$ could think of together that would attract attention to someone flying above.

$\frac{H i s}{R}$ plan worked within hours he was found $\frac{\text { and }}{\mathrm{R}}$ brought back home. From then on he always brought another pilot with $\frac{\text { him }}{R}$ just incase something else like that would happen. 
12LANGA 52090 R-3 S-O E-O C- 18 L-6 Total-27

First I get up and then I get ready to go to school.

$\frac{T}{C}$ I go to school go to science then to English, then W. Geo then $\frac{\text { this }}{R}$ class $\frac{\text { then lunch then math then }}{C}$ P.E. then P.E. then I go home or to work.

$\frac{\text { If } ~}{C}$ work I work then eat $\frac{\text { and }}{C}$ go to bed.

$\frac{\text { If }}{C}$ go home first $I \frac{\text { eat }}{L}$ get the mail watch $T v \frac{\text { then }}{C}$ if it is not raining I play basketball if $\frac{\text { it }}{C}$ is I stay home.

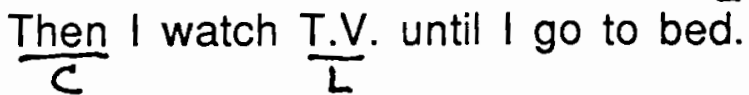


09REGA $42490 \quad R-12 \quad S-4 \quad E-3 \quad C-39 \quad L-31$ Total-89

My days usually begin the same way each day.

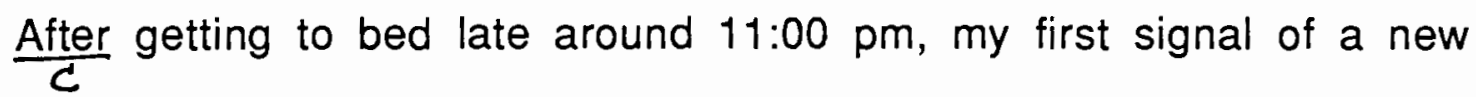
day goes off around 5:50 am.

$\frac{\text { Since }}{\mathrm{C}}$ my best sleep is after my alarm goes off, 1 set another $\frac{\text { one for }}{\mathrm{S}}$ 6:25 am.

Give or take 5 minutes $\frac{\text { and }}{c}$ I'll be in the shower attempting to gain conscience.

A few minutes does the job $\frac{\text { and }}{c}$ then I'm out and getting dressed. My hair is curled and I reach the kithchen by 7:00 am.

$\frac{T h i s}{R}$ gives me enough time to eat cereal with bananas on top and catch $\frac{\text { some morning cartoons. }}{\varepsilon}$.

"Good-bye" I say to my dad as he exits right as I'm eating.

On occasions he'll take me to school, but not now.

I watch the Jetsons for around 10 minutes until, "beep beep" rings in my head.

My ride is here.

Matt $T$., my neighbor up the street $\frac{\text { and }}{L} 1$ are good friends.

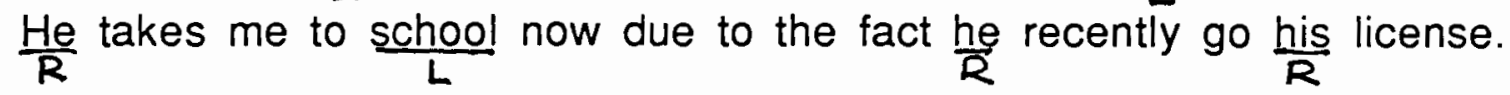

$\frac{H e}{R}$ also is the reason I'm late, if so.

The trip to Beaverton takes about 7 minutes with signals.

As we arrive, we desperately look for places to park.

$\frac{\text { Now }}{C}$ all the tests $\frac{\text { and }}{C}$ quizzes of the day are ringing through my head, causing an overload.

My next $\frac{\text { trip }}{L}$ leads me to my locker, where other classmates are just standing around talking. 
$\frac{\text { After putting my books away, } 1 \text { socialize for a few minutes, and then }}{c}$ head right next to my locker to English class.

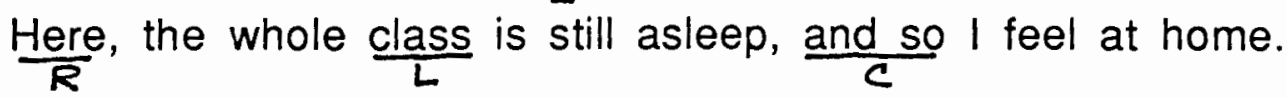

I'm surprised we don't bring pillows for comfort, $\frac{\text { except our teacher }}{c}$ Mrs. N., who has lots of pep.

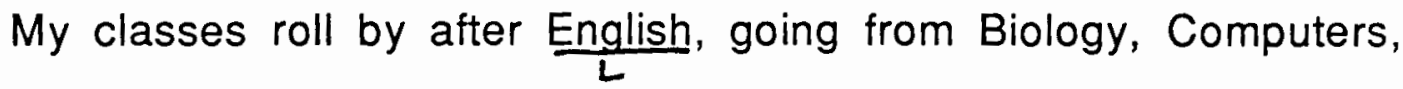
Spanish, and Math to lunch and ending with government.

$\frac{\text { Now }}{C}$ the day is over, and baseball is lined up next.

I am on the junior varsity baseball team for Beaverton, and we practice whenever we don't have games.

In practice, we hit $\frac{\text { and }}{C}$ field, under any form of weather, like "toughguys."

Our carpool brings us home with my truckload of homework.

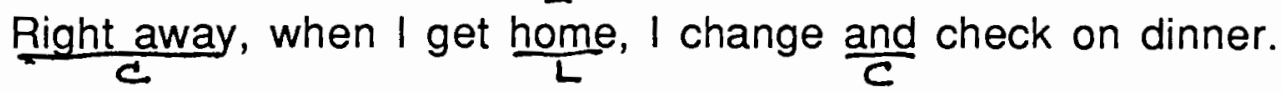

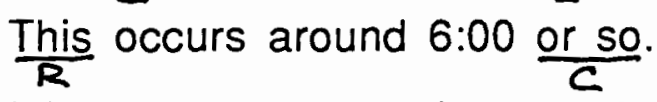

1 immediately jump into my homework then, staying as organized as possible.

The shout "dinner" pops me up from my desk and sends me to the $\frac{\text { kitchen. }}{L}$.

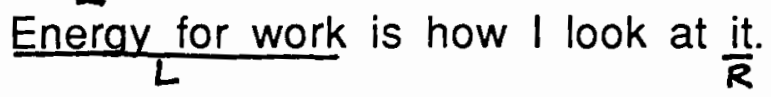

After dinner, I jump right back into my homework.

By 9:00 I'm withered $\frac{\text { and }}{C}$ tired of 3 hours of homework, but I go on with will with an incentive to get good grades.

Sleep is a far off fantasy for me until 10:30.

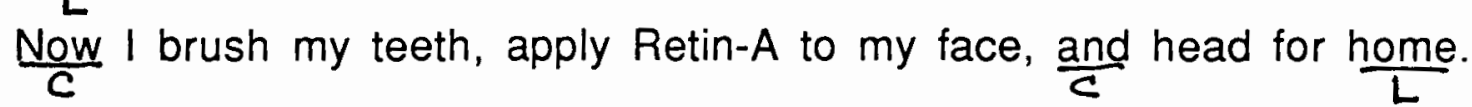
If an reading is required as homework,$I$ do it in bed. 
I'm lucky to be in bed and asleep by $11: 00$, due to so many complications.

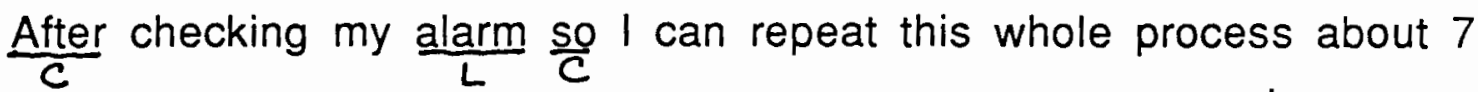
hours from now, I am over-ready to dream happy thoughtsh-ot about school.

Good night! 


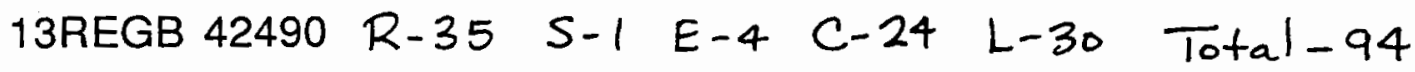

One day, a pilot was flying throught the towering mountains.

$\frac{H i s}{R}$ stereo was very loud $\frac{\text { and }}{C} \frac{h e}{R}$ was drinking beer.

$\frac{T h i s}{R}$ bothered the ten passengers that were on the plane.

$\frac{T}{L} \frac{\text { pilot }}{L} \frac{\text { and }}{C} \frac{\text { his }}{R}$ co-pilot were having a great time.

$\frac{\text { The mountains were jagged and steep, one false move and they would }}{C} \frac{\frac{\text { on }}{C}}{\mathrm{C}}$ crash for sure.

The passengers decided just to kick back and to have a couple drinks themselves.

$\frac{T h e y}{R}$ were going to Las Vegas for a group retreat.

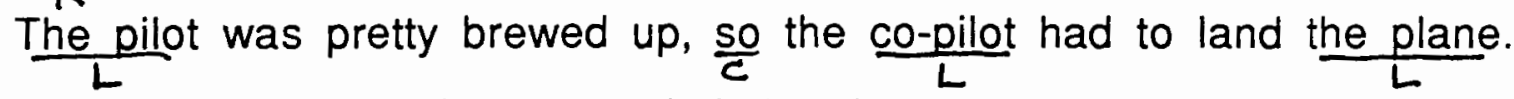

$\frac{T h e y}{R}$ all got off $\frac{\text { and }}{C}$ went to $\frac{\text { their hotel. }}{R}$

$\frac{T h e y}{R}$ went to the resturant $\frac{\text { and }}{C}$ had a couple more drinks $\frac{\text { and }}{C} \frac{\text { they all }}{R}$ had a greasy pork sandwich.

After they ate they went to the casino to gamble.

In the casino they had some more drinks $\frac{\text { and }}{L} \frac{\text { more sandwiches. }}{R} \frac{\text { sand }}{L} \frac{\text {. }}{L} \frac{}{L}$

$\frac{T}{R}$ night they all got sick and vomited in their hotel rooms.

The $\frac{\text { next }}{C}$ morning they all had hangovers $\frac{\text { and }}{C} \frac{\text { they weren't feeling }}{R}$ very well.

The group decided to go eat breakfast to make themselves feel better.

In the restaurant

$\frac{T}{R}$ saw $\frac{L}{R} \frac{1}{L} \frac{\text { pilot }}{L} \frac{\text { and }}{C} \frac{\text { co-pilot, }}{L} \frac{R a y}{L} \frac{\text { and }}{C} \frac{\text { Matt. }}{L}$.

$\frac{T}{R}$ all had breakfast together $\frac{\text { and }}{C}$ played $\frac{K e n o}{L}$ in the restaurant. After three weeks of drinking, eatting, gambling, and getting sick, $\frac{i t}{R}$ was time to go home. 
The group got all their chips together $\frac{\text { and }}{C}$ went to the airport.

The $\frac{\text { co-pilot Matt was there, but the pilot Ray was no where to be }}{L} \frac{}{L}$ seen.

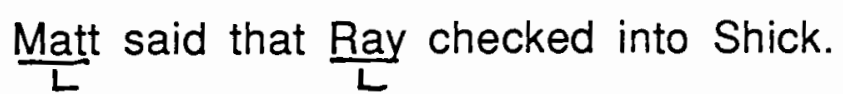

$\frac{I^{\prime} \text { 's }}{R}$ only ten days $\frac{\text { and }}{C}$ a couple of two day follow-ups.

$\frac{T h e y}{R}$ sounded pretty good to the group.

$\frac{\text { It }}{R}$ was a quiet ride back to New York.

When the group got into town they decided to also go to Shick and $\frac{\text { and }}{L}$ fall up to $\frac{\text { their }}{R}$ drinking problems.

$\frac{\text { Some of them }}{\varepsilon}$ even had a chance to turn their lives around, and live the rest of their life alcohol free. 